\title{
Testicular seminoma with large direct iliac nodal metastasis: unusual presentation
}

\author{
Naveen Kumar (10, ${ }^{1}$ Uday Pratap Singh, ${ }^{1}$ Hira Lal, ${ }^{2}$ Sanjoy Kumar Sureka ${ }^{1}$
}

${ }^{1}$ Urology and Renal Transplant, Sanjay Gandhi Postgraduate Institute of Medical Sciences, Lucknow, Uttar Pradesh, India ${ }^{2}$ Radiodiagnosis, Sanjay Gandhi Postgraduate Institute of Medical Sciences, Lucknow, Uttar Pradesh, India

\section{Correspondence to} Dr Sanjoy Kumar Sureka; drsksureka@gmail.com

Accepted 28 May 2020

\section{DESCRIPTION}

A 31-year-old man presented with dull aching on and off right lower abdominal pain of 3 months' duration. There was no history of any medical comorbidities or surgical interventions. Clinically, he had an $8 \times 8 \mathrm{~cm}$ smooth, firm intra-abdominal lump in the right iliac fossa. On genitalia examination, the right testis was present in the right hemiscrotum, and it was approximately $3 \times 5 \mathrm{~cm}$ in size, firm with irregular surface and a hard nodule of approximately $1 \mathrm{~cm}$ on the lateral surface in the mid-part. This testicular abnormality was not noticed by the patient before. On evaluation with ultrasonography, a $7 \times 6 \mathrm{~cm}$ hypoechoic right iliac fossa mass of undetermined nature was present with an $8.7 \times 6.4 \mathrm{~mm}$ well-defined hypoechoic mass in the interpolar region of the right testis with few microlithiases. The patient was then referred for urological consultation where he was further evaluated. Testicular tumour markers were raised mildly with human chorionic gonadotropin (HCG) of $26.34 \mathrm{mIU} / \mathrm{mL}(<5 \mathrm{mIU} / \mathrm{mL})$, lactate dehydrogenase $(\mathrm{LDH})$ of $830 \mathrm{IU} / \mathrm{L}$ and alpha-fetoprotein (AFP) of $7.99 \mathrm{ng} / \mathrm{mL} \quad(0-8.5 \mathrm{ng} / \mathrm{mL})$. Contrastenhanced CT of the abdomen revealed a soft tissue mass of $5.5 \times 6.3 \times 7.5 \mathrm{~cm}$ in the right iliac fossa with central necrosis, anterior to right external iliac vessels and abutting them with maintained fat planes. There was a precaval hypodense mass of $2.2 \times 2.5 \times 4.5 \mathrm{~cm}$ abutting the inferior vena cava

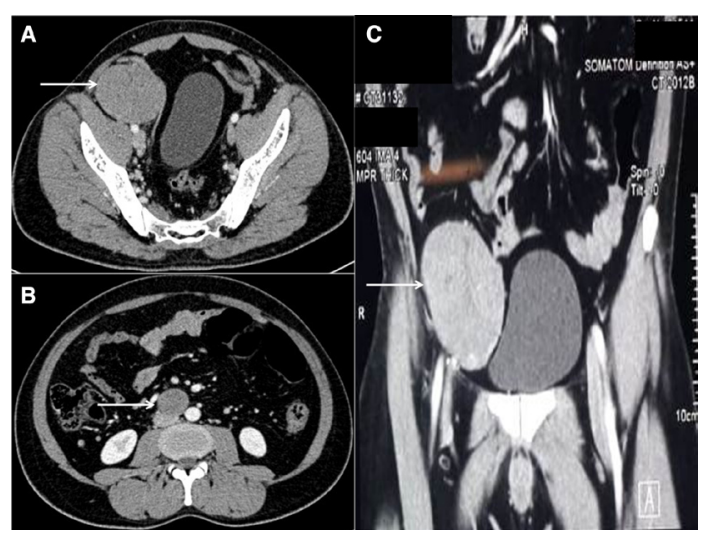

Figure 1 Contrast-enhanced CT abdomen (A) in the axial plane showing a soft tissue mass in the right iliac fossa anterior to the right external iliac vessels and abutting them with maintained fat planes, $(B)$ in the axial plane showing a precaval hypodense mass of $2.2 \times 2.5 \times 4.5 \mathrm{~cm}$ abutting the IVC posteriorly and (C) in the coronal plane showing the right iliac fossa mass displacing the urinary bladder.

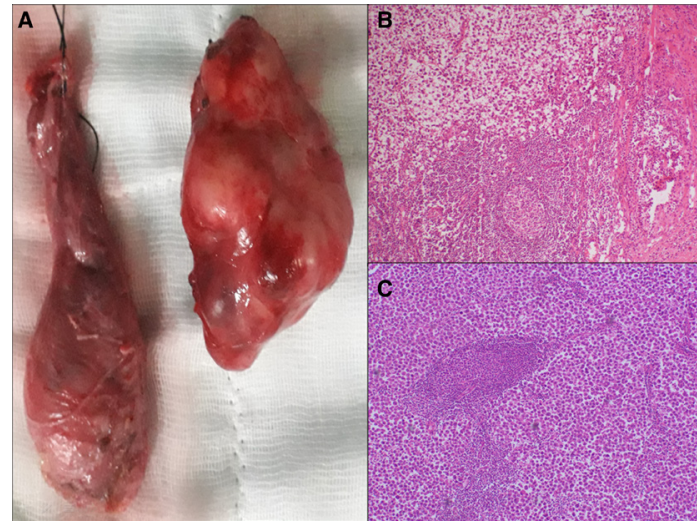

Figure 2 (A) Gross specimen of the right testis and right iliac fossa mass; photomicrograph of (B) the right testis and $(C)$ the right iliac fossa mass showing seminoma with tumour cells disposed in diffuse sheet with intervening fibrous septae containing a small lymphocytic infiltrate.

(IVC) posteriorly and the third part of duodenum anteriorly (figure 1).

He underwent right high inguinal orchidectomy with right iliac fossa mass excision with same incision. Intraoperatively, the right testis was normal sized with an uneven surface and a small nodule in the upper pole. The right iliac fossa mass was firm, circumscribed overlying external iliac vessels with no invasion. The histopathological examination of both the right testis and the right iliac fossa mass showed seminoma with tumour cells disposed in diffuse sheet with intervening fibrous septae containing a small lymphocytic infiltrate (figure 2). The tumour cells displayed moderate pleomorphism, round to oval nuclei, vesicular chromatin,

\section{Patient's perspective}

I was told by my doctor that I have a tumour in my right testis, which is likely malignant and will be removed by surgery, and I also have two other tumours in my abdomen, which may be related to the testicular tumour. My right testis and the larger tumour in my abdomen were removed by surgery and the surgery was uneventful, and the final report was malignant with both tumours of the same type. Presently, I am asymptomatic and have completed my chemotherapy, and I come to the hospital regularly for follow-up as advised by my doctor. I am very happy that my case was managed very well. 


\section{Learning points}

- Direct iliac lymph node metastasis is a rare site of spread for seminomatous germ cell tumors (GCTs) in the absence of bulky retroperitoneal lymphadenopathy or inguinal lymph nodes.

- Testicular tumour should be suspected and testes should always be examined in patients who present with any abdominal lump.

- Histopathological analysis of the inguinal or iliac lump is strongly advised in a patient highly suspicious of having testicular cancer before chemotherapy due to the rarity of the presentation.

prominent nucleoli and an abundant amount of clear to eosinophilic cytoplasm with indistinct cytoplasmic borders. Postorchiectomy tumour markers were normal with HCG of $1.71 \mathrm{mIU} /$ $\mathrm{mL}$ and AFP of $3.35 \mathrm{ng} / \mathrm{mL}$ except for LDH of $933 \mathrm{IU} / \mathrm{L}$.

The patient was started on chemotherapy with three cycles of bleomycin, etoposide and cisplatin in view of good risk T1N2M1a disease, and he has completed the course 2 months ago.

Seminoma is the most common germ cell tumour affecting the testis. Regional or distant metastasis is present at diagnosis in $15 \%$ of pure seminoma. The lymphatic spread of testicular tumours is in a predictable fashion unless the lymphatic drainage from the testes has been altered from prior procedures. ${ }^{1}$ The most common site of tumour dissemination is retroperitoneal lymph nodes. Primary involvement of the iliac or inguinal nodes is rare $\mathrm{r}^{2}$ and associated with tumour extension in the epididymis, breaching of the tunica vaginalis through to the scrotal wall or extension to the vas deferens, or due to previous surgical manipulation of the inguinoscrotal region. ${ }^{3}$ There was no history of any prior surgery in the inguinoscrotal region. Occasional involvement of the iliac nodes can occur in a secondary retrograde fashion, usually when there are bulky retroperitoneal metastases. ${ }^{4}$ However, in our case, the retroperitoneal disease was not bulky. So, rarely, such iliac metastasis may occur in patients with no identifiable risk factors. ${ }^{4}$

The optimal management of non-regional nodal metastasis, including iliac lymph nodes in seminoma, is chemotherapy. However, in our case, a single bulky right iliac fossa mass without any inguinal or bulky retroperitoneal lymph nodes led us to excise the mass along with the right testis to prove the nature of the mass, followed by starting chemotherapy.

\section{Twitter Naveen Kumar @babu_drjmt}

Contributors NK conceived the manuscript, and NK and SKS prepared the manuscript. HL provided the CT images. Consent was obtained by NK. UPS reviewed the manuscript. NK and SKS performed the surgery. The final draft was read and approved by all authors.

Funding The authors have not declared a specific grant for this research from any funding agency in the public, commercial or not-for-profit sectors.

Competing interests None declared.

Patient consent for publication Obtained.

Provenance and peer review Not commissioned; externally peer reviewed.

\section{ORCID iD}

Naveen Kumar http://orcid.org/0000-0001-6176-6913

\section{REFERENCES}

1 Hale GR, Teplitsky S, Truong H, et al. Lymph node imaging in testicular cancer. Trans/ Androl Urol 2018:7:864-74.

2 Ray B, Hajdu SI, Whitmore WF. Proceedings: distribution of retroperitoneal lymph node metastases in testicular germinal tumors. Cancer 1974;33:340-8.

3 Wheeler JS, Babayan RK, Hong WK, et al. Inguinal node metastases from testicular tumors in patients with prior orchiopexy. J Urol 1983;129:1245-7.

4 Mason MD, Featherstone T, Olliff J, et al. Inguinal and iliac lymph node involvement in germ cell tumours of the testis: implications for radiological investigation and for therapy. Clin Oncol 1991;3:147-50.

Copyright 2020 BMJ Publishing Group. All rights reserved. For permission to reuse any of this content visit

https://www.bmj.com/company/products-services/rights-and-licensing/permissions/

BMJ Case Report Fellows may re-use this article for personal use and teaching without any further permission.

Become a Fellow of BMJ Case Reports today and you can:

- Submit as many cases as you like

- Enjoy fast sympathetic peer review and rapid publication of accepted articles

- Access all the published articles

- Re-use any of the published material for personal use and teaching without further permission

Customer Service

If you have any further queries about your subscription, please contact our customer services team on +44 (0) 2071111105 or via email at support@bmj.com.

Visit casereports.bmj.com for more articles like this and to become a Fellow 